\title{
Microcystins (cyanobacteria hepatotoxins) bioaccumulation in fish and crustaceans from Sepetiba Bay (Brasil, RJ)
}

\author{
V.F. Magalhães ${ }^{\mathrm{a}, *}$, M.M. Marinho ${ }^{\mathrm{a}}$, P. Domingos ${ }^{\mathrm{a}}$, A.C. Oliveira ${ }^{\mathrm{a}}$, S.M. Costa ${ }^{\mathrm{a}}$, \\ L.O. Azevedo ${ }^{\mathrm{b}}$, S.M.F.O. Azevedo ${ }^{\mathrm{a}}$ \\ ${ }^{a}$ Laboratório de Ecofisiologia e Toxicologia de Cianobactérias (LETC), Instituto de Biofísica Carlos Chagas Filho, CCS, \\ Universidade Federal do Rio de Janeiro, Rio de Janeiro, RJ 21941-590, Brazil \\ ${ }^{\mathrm{b}}$ DIS/CICT-Fiocruz-Av. Brasil, Rio de Janeiro, RJ 4365, Brazil
}

Received 3 December 2002; accepted 10 June 2003

\begin{abstract}
Blooms of cyanobacteria in water bodies cause serious environmental problems and the occurrence of toxic strains are also related with the human health. Aquatic animals could bioaccumulate microcystins (cyanobacteria hepatotoxins) and so, beyond water, the ingestion of contaminated food represents a human health risk. Recently, WHO recommended a maximum concentration of microcystins (MCYSTs) in drinking water and established the tolerable daily intake (TDI) for consumption of cyanobacteria products contends MCYSTs $\left(0.04 \mu \mathrm{g}^{-1} \mathrm{~kg}^{-1}\right.$ day $\left.{ }^{-1}\right)$. Sepetiba Bay is located in the municipal districts of Rio de Janeiro, Mangaratiba and Itaguaí being an important place of fishing activity. Due to the industrial development in the area, this bay is submitted to different environmental impacts, increasing the organic and industrial pollution. A strain of the nanoplanktonic cyanobacteria Synechocystis aquatilis $f$. aquatilis that produce MCYSTs was already isolated. In this study, we verified MCYSTs presence in muscle tissue of fish and crustaceans, which were harvested monthly in Sepetiba Bay during 11 months, in order to evaluate the potential risk of their ingestion. MCYSTs were analyzed by immunoassay techniques using the ELISA Microcystin Plate Kit (ENVIROLOGIX INC ${ }^{\circledR}$ ) and the concentration were expressed as microcystin-LR equivalent. The analyses of seston samples, water, muscle tissues showed the presence of this cyanotoxin in all samples and it was verified that $19 \%$ of the animals' samples were above the limit recommended by WHO for human consumption. The maximum value found was of $103.3 \mu \mathrm{g} \mathrm{kg}^{-1}$ (TDI $0.52 \mu \mathrm{g} \mathrm{kg}^{-1} \mathrm{day}^{-1}$ ) and the minimum, was $0.25 \mu \mathrm{g} \mathrm{kg}^{-1}$ in crabs muscle tissue (TDI of $0.001 \mu \mathrm{g} \mathrm{kg}^{-1} \mathrm{day}^{-1}$ ). Such data demonstrate that, although in low concentrations, there is already a contamination of fish and crustaceans from Sepetiba Bay. We highlight that the recommended limit refers to healthy adult.
\end{abstract}

(C) 2003 Elsevier Ltd. All rights reserved.

Keywords: Microcystin; Bioaccumulation; Cyanobacteria; Harmful algae

\section{Introduction}

The presence of cyanobacteria hepatotoxins has been documented all over the world. The exposure to microcystins (MCYSTs), the most studied hepatotoxic heptapeptide, was already related to some incidents with animal intoxication (Carmichael, 1992, 1994; Azevedo and

\footnotetext{
* Corresponding author. Tel.: +55-21-2562-6647; fax: +55-212280-8193.

E-mail address: valeria@biof.ufrj.br (V.F. Magalhães).
}

Carmouze, 1994; Falconer, 1998). Intoxication and human death were confirmed in haemodialysis patients from the city of Caruaru (Northeast Brasil) in 1996 (Jochimsen et al., 1998; Carmichael et al., 2001).

Cyanotoxins are rarely ingested by man in amount high enough for a lethal acute dose, but the damage caused by chronic effect is particularly more probable if there is longterm frequent exposure. The maximum allowable concentration for MCYST in drinking water was established in $1 \mu \mathrm{g}^{-1}$ (Falconer et al., 1994). Based on this limit, WHO (World Health Organization) established $0.04 \mu \mathrm{g} \mathrm{kg}^{-1}$ of 
body weight day $^{-1}$ as a tolerable daily intake (TDI) of cyanobacteria products contend MCYSTs (Chorus and Bartram, 1999).

Bioaccumulation of MCYSTs by aquatic animals has been reported by several authors (Tencalla et al., 1994; Vasconcelos, 1995; Williams et al., 1997; Amorim and Vasconcelos, 1999; Thostrup and Christoffersen, 1999). However, these studies were performed in laboratory and there are few studies in field allowing estimate the real danger for human health by oral consumption of aquatic animals that ingest and accumulate MCYSTs (Magalhães et al., 2001a). In that study, the bioaccumulation of MCYSTs equivalent in fish from a coastal lagoon was confirmed and the authors pointed out to the human health risk with the ingestion of contaminated fish.

Considering this fact, it is relevant to monitoring fish and other aquatic animals from water bodies with toxic cyanobacteria species. So, a monitoring program of harmful and toxic phytoplankton was developed in Sepetiba Bay, an important center of fisheries resources.

This bay has been suffering different extractive activities as fishing, exploration of mollusks and wood of mangrove trees, construction of harbor and the development of industrial, tourism and military activities. The industrial development and the population increase contribute with environmental impacts, from the organic to the industrial origin.

Therefore, several factors contribute to increase the modification in the water and air quality of Sepetiba Bay: (i) the release of sanitary garbage (organic pollution); (ii) the deforestation; (iii) the harbor pollution and (iv) the heavy metals pollution from industrial origin, mainly through the rivers, as well as for atmospheric way (Magalhães et al., 1993, 1994, 2001b; Karez, et al., 1994; Magalhães and Pfeiffer, 1995).

However, there is little information about anthropic impact on the phytoplankton community from Sepetiba Bay. Andrade et al. (1993) showed a reduction of the photosynthetic capacity of three phytoplanktonics species isolated from this Bay, when submitted to high concentrations of zinc, and Oliveira and Azevedo (1996), confirm the production of MCYSTs by a nanoplanktonic cyanobacteria isolated from this bay (Synechocystis aquatilis $f$. aquatilis).

This study aimed to verify MCYSTs presence in the aquatic biota, and in the water and seston, as well as to evaluate the potential risk for human by the consumption of local aquatic animals.

\section{Material and methods}

\subsection{Field sampling}

For MCYSTs analysis, fish, crustaceans and water were harvested monthly in Sepetiba Bay (Brasil, RJ) between
January and November 1999. This Bay is a semi-closed bay of $510 \mathrm{~km}^{2}$ with a perimeter of approximately $128 \mathrm{~km}$, situated in the municipal districts of Rio de Janeiro, Mangaratiba and Itaguaí $\left(22^{\circ} 54^{\prime} 06^{\prime \prime} \mathrm{S}\right.$ and $23^{\circ} 04^{\prime} 18^{\prime \prime} \mathrm{S}$; $43^{\circ} 33^{\prime} 42^{\prime \prime} \mathrm{W}$ and $\left.44^{\circ} 02^{\prime} 30^{\prime \prime} \mathrm{W}\right)$. Fish and crustaceans were acquired from fishermen while water and phytoplankton samples were collected in four sample sites, chosen due to its ecological and socioeconomic importance, since Sepetiba Bay, is used as recreational place and fishing resources: (i) SEP01, in the Coroa Grande Inlet, well-known point of pollutants deposit as heavy metals; (ii) SEP02, close to Jaguanum Island, local of large circulation of water; (iii) SEP03, close to the mouth of the main rivers of the east coast of the bay (San Francisco Channel and Guandú River), which transport great amounts of organic and industrial pollutants and (iv) SEP04, close to the City of Sepetiba, the more intern site of the Sepetiba Bay (Fig. 1).

\subsection{Sample analysis}

Phytoplankton was sampled at the surface $(0.2-0.3 \mathrm{~m})$ of the sampling sites. The samples were fixed with lugol's solution and populations were enumerated in random fields (Uhelinger, 1964), using settling technique (Utermöhl, 1958).

In the laboratory water samples were filtered (1 1) onto glassfiber filters (Schleicher and Schuell GF 50-A). The filtrate was concentrated on octadecil-silane cartridges (C18), which was washed with $20 \mathrm{ml}$ of distilled water, followed by $20 \mathrm{ml}$ of $20 \%$ methanol and eluted with $20 \mathrm{ml}$ of $100 \%$ methanol. This last fraction was again concentrated on silica cartridges washed with $20 \mathrm{ml}$ of $100 \%$ methanol and eluted with $20 \mathrm{ml}$ of a solution of $\mathrm{H}_{2} \mathrm{O}$ :TFA:methanol $(10: 0,1: 89,9 \mathrm{v} / \mathrm{v})$ (Tsuji et al., 1994).

The material retained on the filters (seston) was submitted to the extraction with methanol:buthanol:water (20:5:7 v/v) (Krishnsmurthy et al., 1986). Three extractions were performed and the pooled fraction was centrifuged at $510 \mathrm{~g}$. The obtained extract was evaporated to $1 / 3$ of its initial volume and then passed through octadecil-silane cartridges (C 18), which was washed with water and with $20 \mathrm{ml}$ of $20 \%$ methanol and eluted $20 \mathrm{ml}$ of $100 \%$ methanol (Tsuji et al., 1994).

The fraction, with $\mathrm{H}_{2} \mathrm{O}$ :TFA:methanol solution for MCYST analyses in water, and the fraction, which contains $100 \%$ methanol for MCYST analyses in seston, were dried and redissolved in $1.0 \mathrm{ml}$ of deionized water. These suspensions were filtered in nylon filter $(0.45 \mu \mathrm{m})$ and stored at $-20{ }^{\circ} \mathrm{C}$ for subsequent MCYST analyses.

For MCYSTs analyses of fish and crustaceans $5 \mathrm{~g}$ (wet weight) of five animals were pooled, thus each month we had only one sample. Only muscle tissue was analyzed. Each sample was treated with $100 \%$ methanol and then with hexane according to Magalhães et al. (2001a). The obtained methanolic fraction was eluted in C-18 cartridge and then washed and eluted with $30 \mathrm{ml}$ of $20 \%$ methanol and $50 \mathrm{ml}$ of 

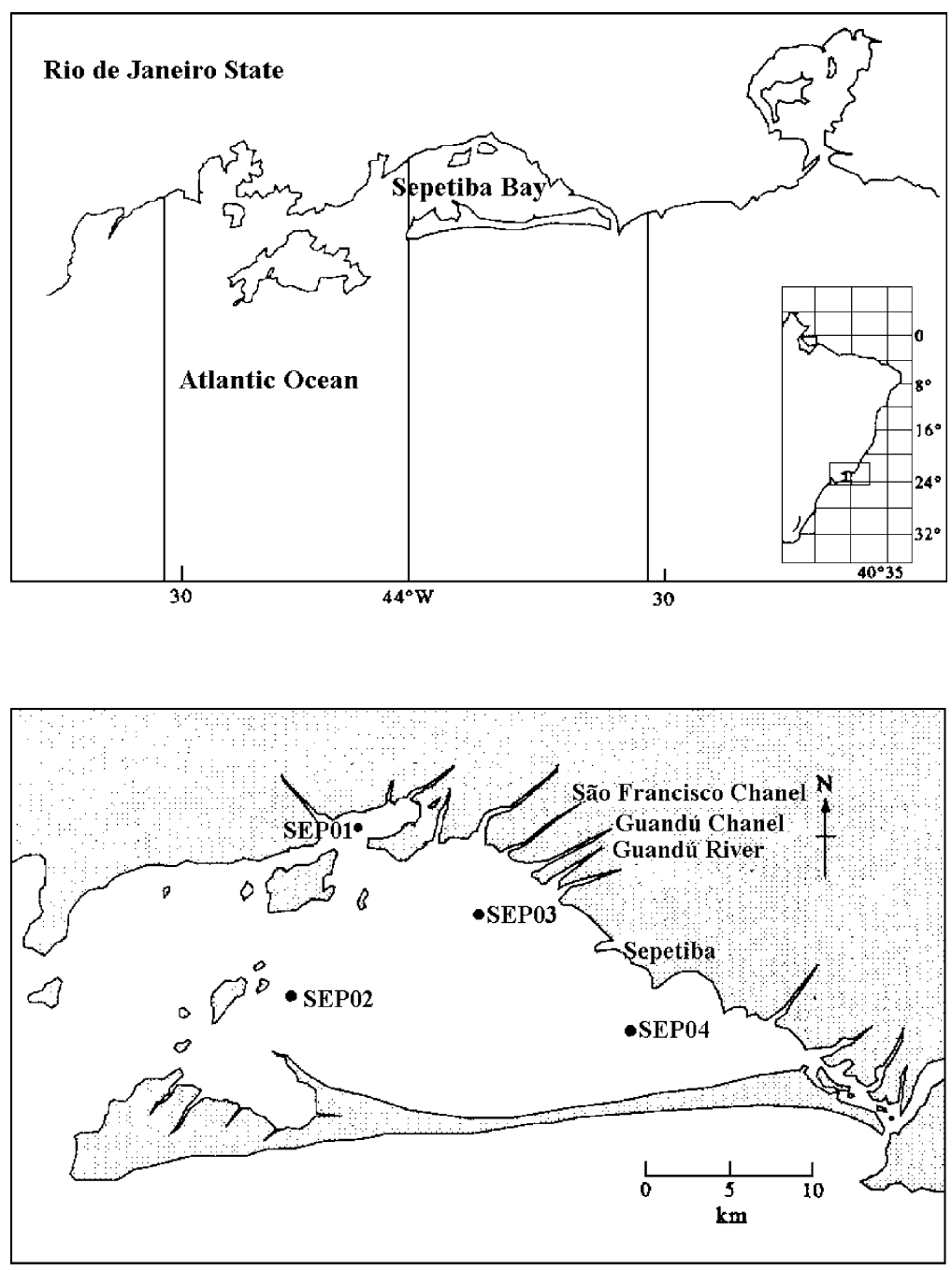

Fig. 1. Location and map of Sepetiba Bay showing the sample sites.

$100 \%$ methanol. The methanolic fraction was dried, redissolved in $1.0 \mathrm{ml}$ of $50 \%$ methanol. These suspensions were filtered in nylon filter $(0.45 \mu \mathrm{m})$ and stored at $-20{ }^{\circ} \mathrm{C}$ for subsequent MCYST analyses.

All samples were analyzed by the immunoassay method using ELISA (ENVIROLOGIX.INC ${ }^{\circledR}$ ). MCYSTs concentrations were expressed as MCYST-LR equivalents.

Relationships between MCYSTs concentration in fish muscle and the concentration in seston and water were assessed using Pearson correlation test.

\section{Results}

The phytoplankton population densities in all sampling sites of Sepetiba Bay varied between 533 cells ml ${ }^{-1}$ (SEP02-June/99) and 30,808 cells ml ${ }^{-1}$ (SEP04-March/99, Fig. 2). Cyanobacteria population densities changed from 0
(SEP01, SEP02 and SEP03-January/99) to 6815 cells ml $^{-1}$ (SEP04-April/99). These values were therefore, always below the limit proposed by the WHO $\left(20,000\right.$ cells $\left.\mathrm{ml}^{-1}\right)$, for protection from health with mild and/or low probabilities of adverse effects related to recreational water. On average, the percentage of cyanobacteria in relation to the total phytoplankton was about $30 \%$.

Reduction in the relative diatoms contribution, and increase in cyanobacteria in all sampling sites, between January and March are shown in Fig. 3. This increment did not represent an increase in the cyanobacteria population, but it was due to a decrease in dinoflagellates and diatoms. From March to November, an alternation between diatoms and cyanobacteria was observed. Skeletonema cf. costatum (diatom) was dominant in January 1999, and in general, diatoms (Centrophycedeae) and picoplanktonic cyanobacteria (unidentified small rod-like cells around $2 \mu \mathrm{m}$ long) during the other studied months. 


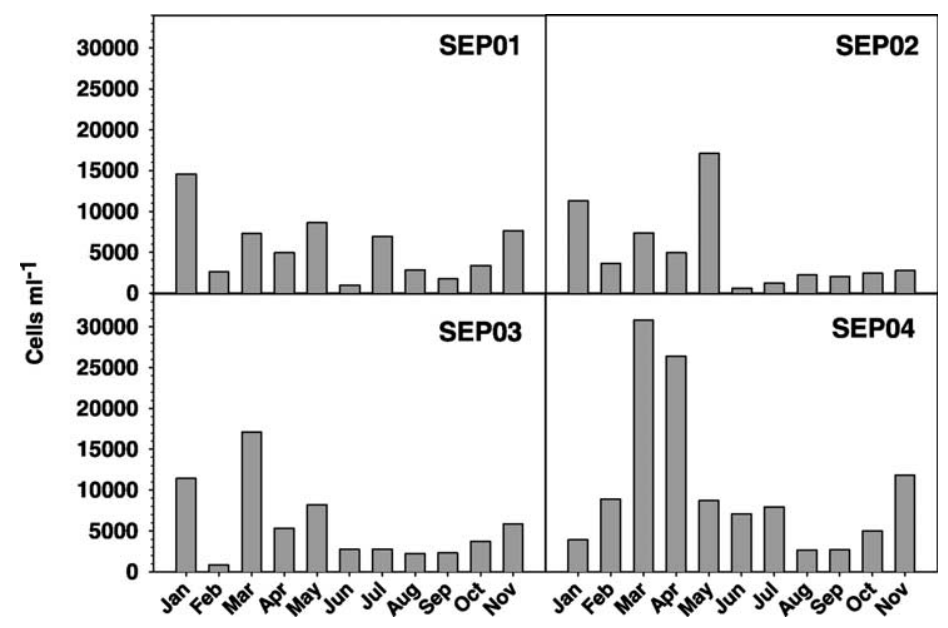

Fig. 2. Phytoplankton density in the four sampling sites of Sepetiba Bay.

It was also observed the occurrence of another phytoplankton genus known as potentially producers of different toxins: dinoflagellates (Prorocentrum, Gymnodinium and Dinophysis) and diatoms (Pseudonitzchia). It is noteworthy that in May, the genus Gymnodinium was dominant (29\%) at sampling site SEP03.

MCYSTs were detected in all water and seston samples. In water samples, the concentration was below the limit proposed by the WHO in $1 \mu \mathrm{g} 1^{-1}$ with the highest value $\left(0.12 \mu \mathrm{g} \mathrm{l}^{-1}\right)$ found in June 1999 on SEP02 (Fig. 4). The highest value in seston samples was observed in January 1999 on SEP03 $\left(0.78 \mu \mathrm{g} \mathrm{l}^{-1}\right)$, very close to the proposed value (Fig. 5).
MCYSTs were also present in all organism samples (fish muscle, shrimp and crab). The highest value was found in January 1999, when the crab sample reached $103.3 \mu \mathrm{g} \mathrm{kg}^{-1}$ and fish muscle, $39.6 \mu \mathrm{g} \mathrm{kg}^{-1}$ (Fig. 6a). It is important to point out that there was no sampling in August.

In agreement with the WHO recommendations, the TDI of food containing MCYSTs (TDI) is $0.04 \mu \mathrm{g} \mathrm{kg}^{-1}$ of body weight a day. Considering an adult of $60 \mathrm{~kg}$, who ingests, on the average, $300 \mathrm{~g}$ of fish, crab or shrimp a day, we can verify that three of the 16 analyzed samples (19\%) were above this limit (Fig. 6b). The crab sample harvested in January presented an estimated daily intake of
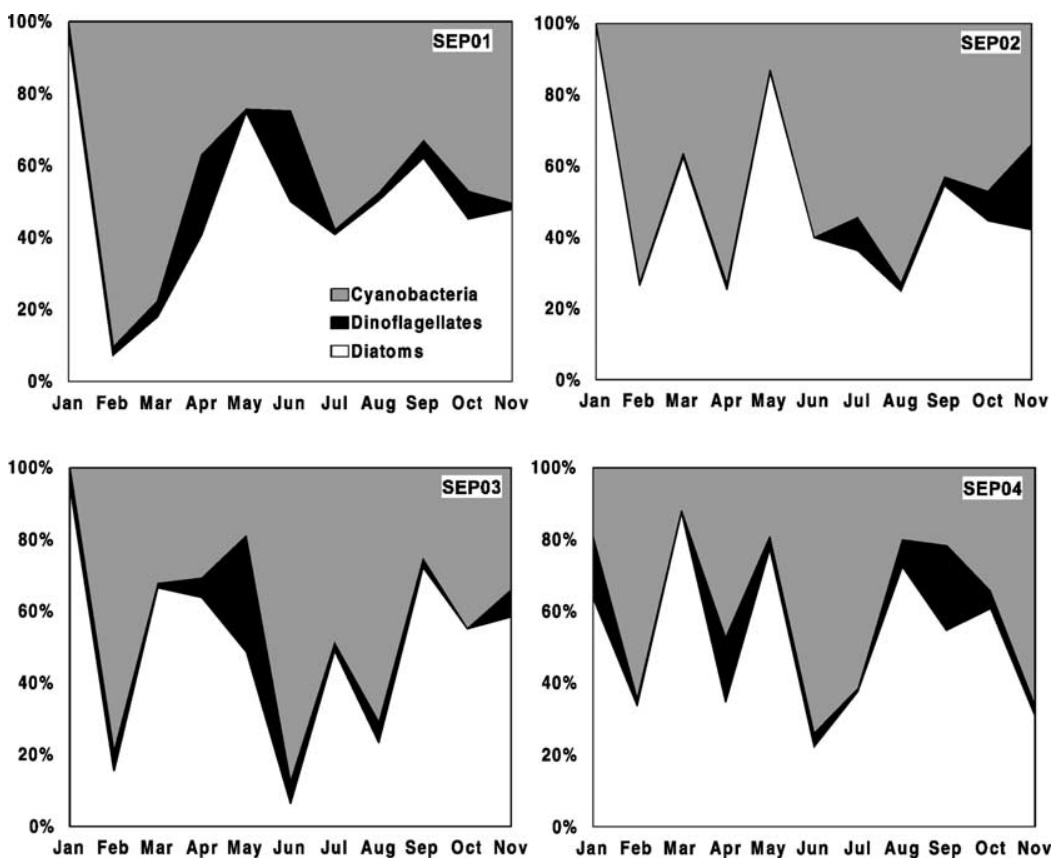

Fig. 3. Percentage of occurrence of the three main phytoplanktonic classes observed in the Sepetiba Bay, in the four sampling sites. 


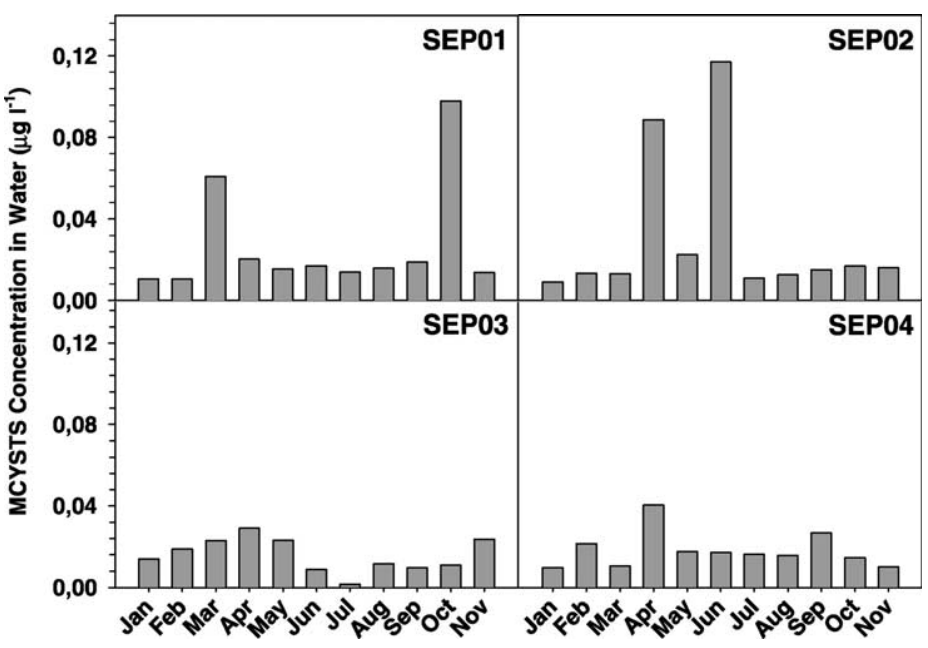

Fig. 4. Microcystins concentration in water samples.

$0.198 \mu \mathrm{g} \mathrm{kg}^{-1}$ day, (13 times above the recommended limit).

Significant correlation was observed between MCYSTs concentration in seston samples and in fish muscle $(r=$ $0.96, p<0.05)$ and between water samples and fish muscle $(r=-0.27, p<0.05)$.

\section{Discussion}

The occurrence of harmful and toxic phytoplankton has increased during the last years in frequency, intensity and geographic distribution. This problem can cause different and severe economic losses in fisheries, tourism and in relation to aquaculture, mainly bivalve shellfish and crustaceans and fin fish larvae that are filter feeding (Geohab, 1998). Furthermore, the ingestion of contaminated aquatic animal by toxic microalgae can affect human health causing gastrointestinal and neurological illnesses.

The genus Skeletonema, dominant in January 1999, and Chaetoceros which are non-toxic to humans, in concentration above $10^{6}$ cells $1^{-1}$ are considered potentially harmful to fish and invertebrates by damaging or clogging their gills (Hallegraeff, 1995). In South Korea, in their monitoring program, the fisheries product harvesting area is closed when the density of these cells were above $10^{6}$ cells $\mathrm{ml}^{-1}$. In this study, we observed the population densities of these harmful phytoplankton above this limit in January and May 1999.

Toxins produced by phytoplankton are separated in five groups according to their different effects: Paralytic Shellfish Poisoning (PSP); Diarrhetic Shellfish Poisoning (DSP); Neurotoxic Shellfish Poisoning (NSP); Amnesic Shellfish Poisoning (ASP) and Ciguatera Shellfish Poisoning (Geohab, 1998).

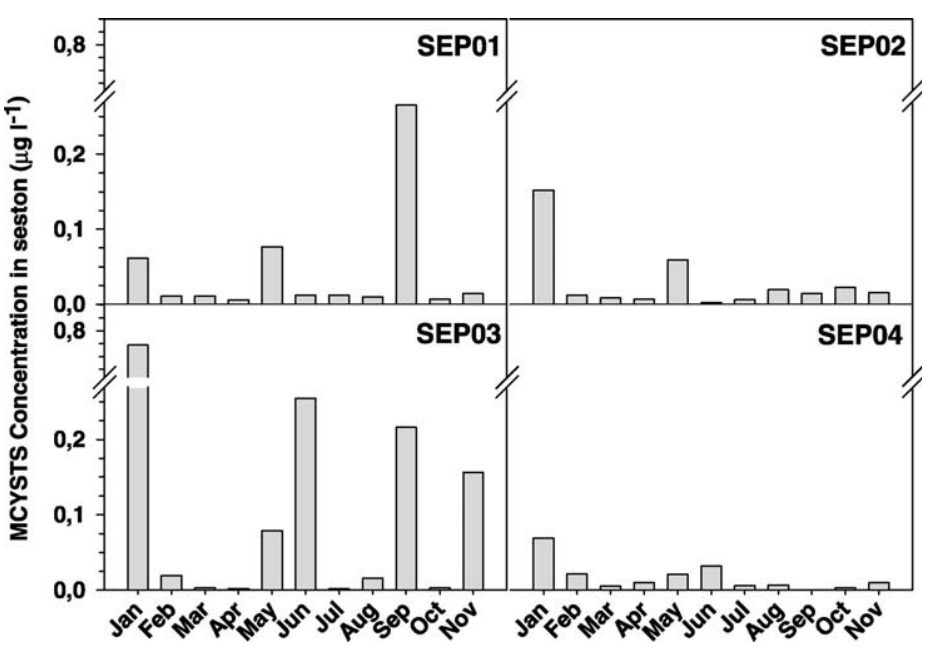

Fig. 5. Microcystins concentration in seston samples. 

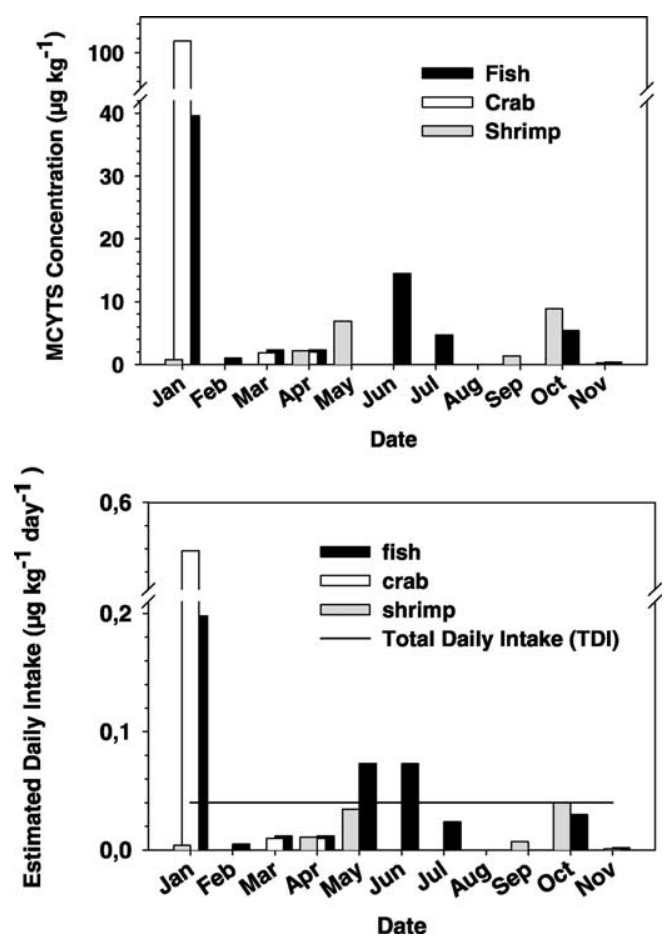

Fig. 6. (a) Microcystins concentration in fish muscles, shrimp and crab collected in Sepetiba Bay. (b) Variation of the esteemed values of daily consumption of microcystins (TDI) starting from the concentration observed in the analyzed animals. The line represents the allowed daily total ingestion, established by WHO.

During this study, phytoplankton genus producers of potent toxins, constituting serious risk for the human health through the ingestion of contaminated aquatic organism, was observed (Geohab, 1998). The dinoflagellates Prorocentrum and Dinophysis are potentially DSP producers, and the genus Gymnodinium is potentially PSP and NSP producer, depending on the specie. The diatom Pseudonitzchia is potentially ASP producer.

In eight of the twelve studied months, picoplankton cyanobacteria was dominant in most of the sampling sites and it was already known that picoplanktonic cyanobacteria is a potentially microcystin producer (Domingos et al., 1999; Komárek et al., 2001). MCYSTs were present in all water and seston samples and we assume that this toxin came from toxic picoplanktonic cyanobacteria. Furthermore, these toxins were also present in all aquatic organisms analysed.

A rapid transference of MCYSTs from seston to fish was observed in other field study (Magalhães et al., 2001a). In this study, the positive Pearson correlation between MCYSTs concentration in seston samples and in fish muscle is thought as the direct transference of these toxins to the fish through oral ingestion, probably from picoplankton cyanobacteria.
This hepatotoxin can be degradated by bacteria and can be removed from water by clay material (Rapala et al., 1994; Morris et al., 2000; Park et al., 2001). In this study, the highest MCYSTs concentration was observed in crab samples collected in January. Once these animals are detritivorous, it is possible that this toxin would be adsorbed by sediment particles thus, crabs contamination became via particle feeding.

Our data show that, although in low concentrations, there is already a contamination of the organisms of the Sepetiba Bay for these hepatotoxins and, therefore the authorities of human health should be alerted properly for that risk of human intoxication.

In synthesis, (i) the increase of the relative abundance of potentially toxic cyanobacteria; (ii) the occurrence of harmful species of phytoplankton (dinoflagellates and diatoms) during the study; (iii) the MCYSTs occurrence in all water, seston and aquatic organisms sample and, finally, (iv) MCYSTs values above TDI established by WHO $\left(0,04 \mu \mathrm{g} \mathrm{kg}^{-1} \mathrm{day}^{-1}\right)$ in $25 \%$ of muscle of fish and crustaceans samples suggest that the Sepetiba Bay is suffering an eutrophication process caused by human activities. We also demonstrates the needs of the fisheries in this bay to be strictly monitored to avoid human intoxication.

\section{Acknowledgements}

We would like to thank Prof. Vera L.M. Huszar, Federal University of Rio de Janeiro, Brasil for review helpful editorial changes to this manuscript. This work was supported by SMAC (Municipal Environmental Bureau of the city of Rio de Janeiro) and CNPq/PRONEX.

\section{References}

Amorim, A., Vasconcelos, V., 1999. Dynamics of microcystins in the mussel Mytilus galloprovincialis. Toxicon 37, 1041-1052.

Andrade, L., Azevedo, S.M.F.O., Pfeiffer, W.C., 1993. Primary production and photosynthetic activity of 3 phytoplankton species cultivated under high $\mathrm{Zn}$ concentration. Fresenius Environ. Bull. 2, 503-508.

Azevedo, S.M.F.O., Carmouze, J., 1994. Une mortalité de poissons dans une lagune tropicale (Brésil) durant une période de dominance de cyanophyceae. Coincidence ou conséquence? Ver. Hydrobiol. Trop. 27 (3), 265-272.

Carmichael, W.W., 1992. Cyanobacteria secondary metabolites: the cyanotoxins. J. Appl. Bacteriol. 72, 445-459.

Carmichael, W.W., 1994. The toxins of cyanobacteria. Sci. Am. 270 (1), 78-86.

Carmichael, W.W., Azevedo, S.M.F.O., An, J.S., Molica, R.J.R., Jochimsen, E.M., Lau, S., Rinehart, K.I., Shaw, G.R., Eaglesham, G.K., 2001. Human fatalities from cyanobacteria: chemical and biological evidence for cyanotoxins. Environ. Health Perspect. 39, 341-344. 
Chorus, I., Bartram, J., 1999. Toxic cyanobacteria in water, A guide to public health consequences, monitoring and management, $\mathrm{E}$ and FN Spon on behalf of WHO, London, $416 \mathrm{pp}$.

Domingos, P., Rubim, K.T., Molica, R.J.R., Azevedo, S.M.F.O., Carmichae, L.W.W., 1999. First report of microcystin production by picoplanktonic cyanobacteria isolated from a northeast brazilian drinking water supply. Environ. Toxicol. 14 (1), 31-35.

Falconer, I.R., 1998. Algal toxins and human health. In: Hrubec, J., (Ed.), The Handbook of Environmental Chemistry, vol. 5, part C. Quality and Treatment of Drinking Water II, Springer, Berlin, pp. 53-82.

Falconer, I.R., Burch, M.D., Steffensen, D.A., Choice, M., Coverdale, O.R., 1994. Toxicity of the blue-green alga (cyanobacterium) Microcystis aeruginosa in drinking water to growing pigs, as an animal model for human injury and risk assessment. Environ. Toxicol. Water Qual. 9, 131-139.

Geohab, 1998. The global ecology and oceanography of harmful algal blooms, Report from a Joint IOC/SCOR Workshop. Havreholm, 43 pp.

Hallegraeff, G.M., 1995. Harmful algal blooms: a global overview. In: Hallegraeff, G.M., Anderson, D.M., Cembella, A.D. (Eds.), Manual on Harmful Marine Microalgae. IOC Manuals and Guides No. 33, UNESCO, pp. 1-22.

Jochimsen, E.M., Carmichael, W.W., An, J., Cardo, D.M., Cookson, S.T., Holmes, C.E.M., Antunes, E.A., Melo Filho, D.A., Lyra, T.M., Barreto, V.S.T., Azevedo, S.M.F.O., Javis, W.R., 1998. Liver failure and death following exposure to microcystin toxins at a hemodialysis center in Brazil. N. Engl. J. Med 338 (13), $873-879$.

Karez, C.S., Magalhães, V.F., Pfeiffer, W.C., Amado Filho, G.M., 1994. Trace metal accumulation by algae in Sepetiba Bay, Brazil. Environ. Pollut. 83, 351-356.

Komárek, J., Azevedo, S.M.F.O., Domingos, P., Komárková, J., Tichú, M., 2001. Background of the Caruaru tragedy: a case taxonomic study of toxic cyanobacteria. Algol. Stud. 103, 9-29.

Krishnsmurthy, T., Carmichael, W.W., Saver, E., 1986. Toxic peptides from freshwater cyanobacteria (blue-green algae). I. isolation, purification and characterization of peptides from Microcystis aeruginosa and Anabaena flos-aquae. Toxicon 24, $865-873$.

Magalhães, V.F., Pfeiffer, W.C., 1995. Arsenic concentration in sediments near a metallurgical plant (Sepetiba Bay, Rio de Janeiro, Brazil). J. Geochem. Explor. 52, 175-181.

Magalhães, V.F., Karez, C.S., Guimarães, J.R.D., Pfeiffer, W.C., 1993. Radiotracer studies of lead bioaccumulation by Padina gymnospora (Phaeophyceae). Fresenius Environ. Bull. 2, 200-205.
Magalhães, V.F., Karez, C.S., Pfeiffer, W.C., Guimarães, J.R.D., 1994. Chromium and zinc accumulation by Padina gymnospora (Phaeophyceae) from a contaminated tropical coastal area. Fresenius Environ. Bull. 3, 300-305.

Magalhães, V.F., Soares, R.M., Azevedo, S.M.F.O., 2001 a. Microcystin contamination in fish from the Jacarepaguá Lagoon (RJ, Brazil): Ecological implication and human health risk. Toxicon 39, 1077-1108.

Magalhães, V.F., Carvalho, C.E.V., Pfeiffer, W.C., 2001b. Arsenic contamination and dispersion in the Engenho Inlet, Sepetiba Bay, SE, Brazil. Water, Air, Soil Pollut. 129 (1/4), 83-90.

Morris, R.J., Willians, D.E., Luu, H.A., Holmes, C.F.B., Andersen, R.J., Calvert, S.E., 2000. The adsorption of microcystin-LR by natural clay particles. Toxicon 38, 303-308.

Oliveira, A.C.P., Azevedo, S.M.F.O., 1996. Produção de hepatotoxinas por Synechocystis aquatilis $f$. aquatilis em cultivo misto com Monoraphidium convolutum, In: IV Congresso LatinoAmericano de Ficologia. Caxambu (MG),.

Park, Ho-D., Sasaki, Y., Maruyama, T., Yanagisawa, E., Hiraishi, A., Kato, K., 2001. Degradation of cyanobacterial hepatotoxin microcystin by a new bacterium isolated from a hypertrophic lake. Environ. Toxicol. 16, 337-343.

Rapala, J., Lahti, K., Sivonen, K., Niemela, S.I., 1994. Biodegradability and adsorption on lake sediments of cianobacterial hepatotoxins and anatoxin-a. Lett. Appl. Microbiol. 19, 423-428.

Tencalla, F., Dietrich, D., Schlatter, C., 1994. Toxicity of Microcystis aeruginosa peptide toxins to yearling rainbow trout (Oncorhynchus mykiss). Aquat. Toxicol. 30, 215-224.

Thostrup, L., Christoffersen, K., 1999. Accumulation of microcystins in Daphnia magna feeding on toxic Microcystis. Arch. Hydrobiol. 145 (4), 447-467.

Tsuji, K., Naito, S., Kondo, F., Watanabe, M.F., Suzuki, S., Nakazawa, H., Suzuki, M., Shimada, T., Harada, K., 1994. A clean-up method for analysis of trace amounts of microcystins in lake water. Toxicon 32 (10), 1251-1259.

Uhelinger, V., 1964. Étude statisque des méthodes de dénobrement planctonique. Arch. Sci 17, 121-123.

Utermöhl, H., 1958. Zur vervollkommung der quantitativen phytoplankton methodik. Mitt. Int. ver. Theor. Angew. Limnol 9, 1-38.

Vasconcelos, V.M., 1995. Uptake and depuration of the heptapeptide toxin microcystin-LR in Mytilus galloprovincialis. Aquat. Toxicol. 32, 227-237.

Williams, D.E., Dawe, S.C., Kent, M.L., Andersen, R.J., Craig, M., Holmes, C.F.B., 1997. Bioaccumulation and clearence of microcystins from salt water mussels. Mytilus edulis, and in vivo evidence for covalently bound microcystins in mussels tissues. Toxicon 35 (11), 1617-1625. 